\title{
Kísérletek szilícium egykristályon femtoszekundumos lézerrel
}

\section{Experiments with femtosecond laser on monocrystalline silicon}

\author{
Maloveczky Anna, ${ }^{1}$ Windisch Márk, ${ }^{2}$ Szabó Dávid, ${ }^{3}$ Buza Gábor, ${ }^{4}$ Ugi Dávid, ${ }^{5}$ \\ Veres Miklós, ${ }^{6}$ Rigó István, ${ }^{7}$ Fürjes Péter, ${ }^{8}$ Hakkel Orsolya ${ }^{9}$ \\ 1,2,3,4 Bay Zoltán Alkalmazott Kutatási Közhasznú Nonprofit Kft. Budapest, Magyarország, \\ anna.maloveczky@bayzoltan.hu, mark.windisch@bayzoltan.hu,david.szabo2@bayzoltan.hu, \\ gabor.buza@bayzoltan.hu \\ ${ }^{5}$ Eötvös Loránd Tudományegyetem. Budapest, Magyarország, ugidavid42@gmail.com \\ 6,7 Wigner Fizikai Kutatóközpont, Budapest, veres.miklos@wigner.mta.hu, rigo.istvan@wigner.mta.hu \\ ${ }^{8,9}$ Energiatudományi Kutatóközpont, Budapest, furjes@mfa.kfki.hu, hakkel@energia.mta.hu
}

\begin{abstract}
Experiments were performed with femtosecond laser on monocrystalline silicon for different application fields. The small focal spot diameter, the ultra-short pulse length, and the high energy density opens new ways in material processing; the treated material will have smaller heat affected zone (HAZ), and allow more precise, higher quality material processing. Micropillars and LIPSS structures were prepared on monocrystalline silicon in our study.
\end{abstract}

Keywords: femtosecond laser, surface structuring, micromachining, micropillar.

\section{Összefoglalás}

Femtoszekundumos lézer segítségével különböző felhasználási célokkal kísérleteztünk szilícium egykristályon. A kis fókuszfoltátmérő, az ultrarövid impulzushossz és a nagy energiasűrűség új utakat nyit meg az anyagmegmunkálásban; a kezelt anyagon kisebb lesz a hőhatásövezet (HAZ), valamint precízebb, jobb minőségű anyagmegmunkálás válik lehetővé. Munkánk során szilícium egykristályra mikrooszlopokat, valamint lézerindukált periodikus felületi struktúrákat készítettünk.

Kulcsszavak: femtoszekundumos lézer, felületstrukturálás, mikromegmunkálás, mikrooszlop.

\section{Szakirodalmi összefoglaló}

Az elmúlt néhány évtizedben gyors fejlődésen mentek keresztül az ultrarövid impulzusú lézerek (azaz a piko- és femtoszekundumos lézerek). Ezeknek a lézereknek számos előnyük van a hagyományos (pl. nanoszekundumos) impulzuslézerekhez képest. A rendkívül rövid impulzusok eredményeként a hőhatásövezet mérete sokkal kisebb a kezelt anyagokban, ami kiváló minőségű megmunkálást tesz lehetővé a lágyabb és a kemény, rideg anyagok esetében egyaránt. Ennek magyarázata az, hogy az elektronoknak a kezelt anyag elektron-fonon kölcsönhatási erősségétől függően 1-100 ps-ra van szükségük ahhoz, hogy a termikus energiát át tudják adni a rácsban lévő atommagoknak. Ez a femtoszekundumos lézereknél ahhoz vezet, hogy a besugárzott energiának csak egy nagyon kis része képes hővé alakulni.

Az ultrarövid impulzusú lézerek másik előnye az, hogy rendkívül nagy impulzusteljesítményt tudnak generálni, ami lehetővé teszi a multifotonos abszorpció végbemenését, s így szigetelő- 
anyagok is megmunkálhatóak vele (pl. üveg). Az egyfotonos abszorpció nem képes a szigetelőanyagok elektronjait a vezetési sávba gerjeszteni. Azonban a multifotonos abszorpció során a nagy fotonsűrüség miatt akkor is lehetővé válik az elektronok vezetési sávba gerjesztése, ha a tiltott sáv energiája nagyobb, mint a fotoné [1-6].

A fent leírtak miatt a femtoszekundumos lézerek képesek kiváló minőségben hiperszublimálni. Hiperszublimáció a nagy teljesítményű impulzuslézeres kezelés során alakul ki: plazmaállapotú anyagfelhő lép ki az anyagból, és jól definiált gödröt, mélyedést hagy maga után. A szilárd anyag közvetlenül plazmafázisba alakul [1].

Így kimunkálhatók mikrooszlopok, mikrocsatornák, mikrofuratok, valamint sztentek is.

A mikrooszlopokat anyagkutatási célokra használják. A képlékeny alakváltozás máshogy müködik mikroszinten, aminek a megismerése a mikroméretű alkatrészek elterjedése és a diszlokációelmélet fejlesztése szempontjából fontos. A munkánk során ún. előmunkált mikrooszlopokat munkáltunk ki, hogy a FIB-bel (fókuszált ionnyaláb) való, időigényes megmunkálási időt lecsökkentsük [7-11].

A hiperszublimációs küszöb alatt szabályos, hullámszerű szerkezeti formák, úgynevezett lézerindukált periodikus felületi struktúrák jelennek meg a felületen. Ezeknek a hullámoknak a periódusa sokkal kisebb, mint a lézersugár foltátmérője. Kialakulásuk mechanizmusára egyelőre nem létezik elfogadott magyarázat, de az eddigi elméletek szerint főként a beeső és a felületről visszaszórt elektromágneses hullámok interferenciája és hidrodinamikai jelenségek játszanak szerepet benne. Az így strukturált felületeket fel lehet használni például a tribológiai tulajdonságok javítására, antibakteriális felületek kialakítására, valamint a SERS- (felületerősített Raman-spektroszkópia) spektroszkópiában szubsztrátként. A Raman-spektroszkópiában gyakori probléma, hogy a vizsgálandó komponens csak kis menynyiségben van jelen az oldatban, például gerincvelőfolyadék-vizsgálatnál vagy szűrt vízben visszamaradó gyógyszermolekulák detektálása során. Ebben az esetben nem elég nagy az anyag Raman-jele ahhoz, hogy ki lehessen mutatni a jelenlétét. Ekkor egy SERS-chipet (szubsztrátot) helyeznek a Raman-mikroszkópba, amire rácsöppentve az oldatot, az képes felerősíteni a jelet akár 1014-szeresére is [12, 13].

A SERS-erősítés fő (elektromágneses) oka az, hogy a külső elektromágneses tér hatására a fémek felületén lévő szabadelektronok oszcillálni kezdenek: ez egy kvázirészecske, amit plazmonnak neveznek. Ha ezek rezonanciafrekvenciája a külső tér frekvenciájával megegyezik, akkor felerősödik az elektromágneses tér intenzitása. Ez jelentheti a gerjesztő vagy a szórt, de akár mindkét fény elektromágneses terének felerősítését is $[14,15]$.

A fent részletezett felhasználásokra természetesen nem csak lézersugaras eljárással lehet az adott struktúrát elkészíteni, mert például SERS-szubsztrát készítése elektrokémiai módszerekkel is megvalósítató. Azonban a lézersugaras kezelésnek számos előnye van: nagy termelékenység, megismételhetőség, precíz megmunkálás, lokalizálhatóság [1].

\subsection{A használt lézer- és vizsgálóberendezé- sek}

A lézersugárforrás Coherent Monaco típus. A sugárvezetés szál nélkül, tükrök segítségével történik a Scanlab gyártmányú z-kompenzációs lencsébe, majd a galvanotükrös F-theta lencsébe. Az ismétlési frekvencia: $188 \mathrm{kHz}$-től $50 \mathrm{MHz}-\mathrm{ig}$ állítható, ami lehetővé teszi a berendezés ipari alkalmazásokra történő használatát is. Az impulzushossz 300 fs-től 10 ps-ig állítható. A maximális átlagteljesítmény $62 \mathrm{~W}$, a maximális impulzusenergia pedig $200 \mu \mathrm{J}$. Azonban a maximális impulzusteljesítmény $600 \mathrm{MW}$, ami rendkívül nagy energiasűrűséget jelent. Összehasonlításképpen, 500 MW 1 db paksi atomerőmű blokk teljesítménye. A lézersugárzás hullámhossza 1064 nm, a fókuszfoltátmérő pedig $80 \mu \mathrm{m}$ volt.

A képalkotást Keyence VHX 2000-es mikroszkóppal, a SEM-felvételeket Quanta FEG 3D elektronmikroszkóppal végeztük.

A Raman-vizsgálatokat pedig Renishaw InVia micro-Raman-spektrométerrel végeztük.

\subsection{Mikrooszlopok előállítása}

Egy mikrooszlopot FIB-bel elkészíteni akár egy napig is tarthat. A munkánk során előmikrooszlopot munkáltunk ki, amit később FIB-es utómunkával tökéletesítettünk. A lézerberendezésünkkel néhány perc alatt készíthető el több száz előmunkált mikrooszlop.

A mikrooszlopok elkészítése során négyzethálós elrendezésben árkokat munkáltunk szilícium egykristály lapkákba, az így kialakított árkok közötti részek a mikrooszlopok. Egy-egy ilyen, általunk készített oszlop néhány tíz mikrométer, de akár egy milliméter magas is lehet (lásd 1., 2. ábra). 


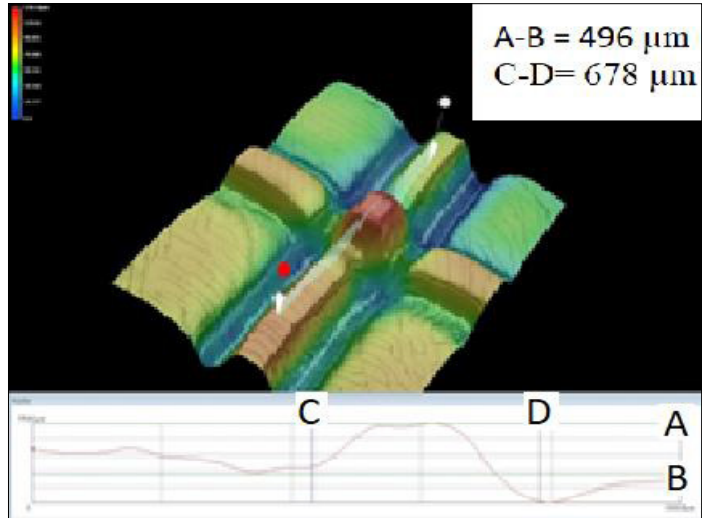

1. ábra. 500 mikrométer magas mikrooszlop 3D optikai mikroszkópos felvétele és topográfiai grafikonja

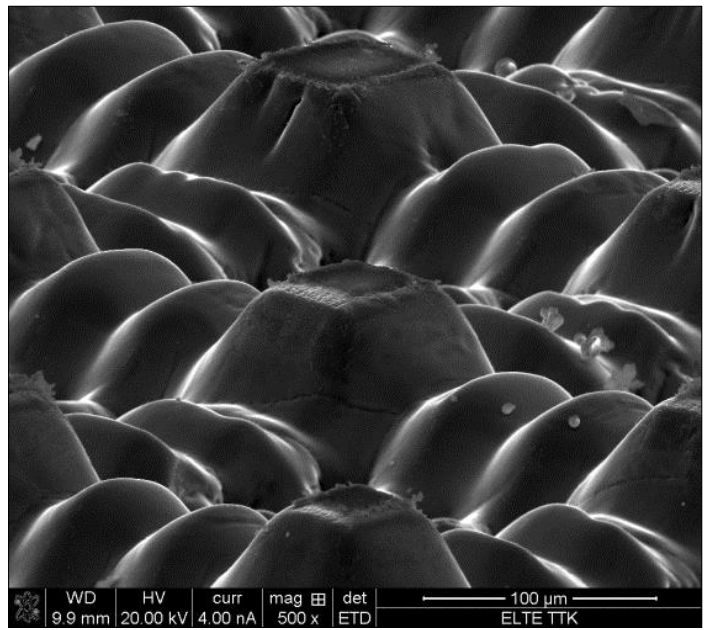

2. ábra. 50 mikrométer magas mikrooszlop SEM-felvétele

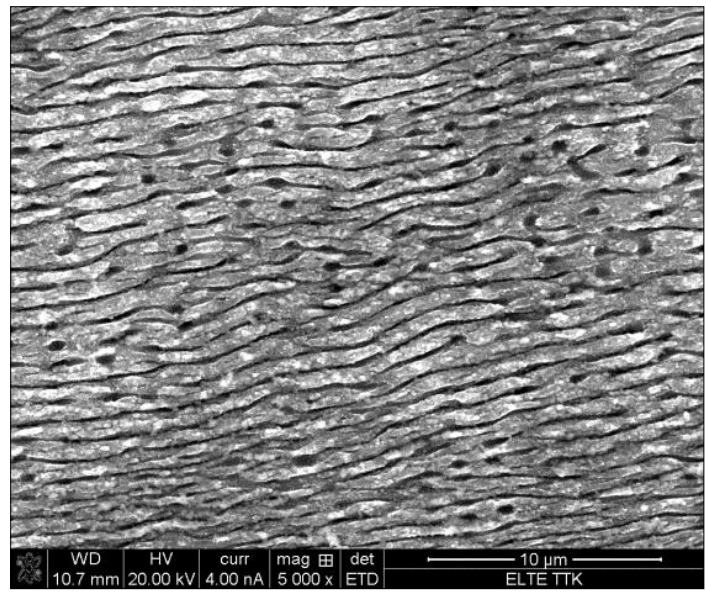

3. ábra. A 360× erősítési faktorú minta SEM-felvétele, aranyozás előtt
Az anyagfizikai modell megalkotásának szempontjából fontos, hogy az oszlop tökéletes egykristály maradjon, így a hőhatásövezet jelenléte nem megengedett. A kisebb, 20-60 mikrométer magasságú oszlopoknál elhanyagolható hőhatásövezetet mértünk EBSD-vel (visszaszórt-elektron diffrakció), amit a FIB-es utómunka során könnyedén és gyorsan el lehet távolítani. Ezzel szemben a nagyobb, több száz mikrométer magas oszlopoknál már jelentős, 20-30 mikrométer vastag hőhatásövezettel kell számolni. Azonban a vastagsága ebben az esetben is tovább csökkenthető, a lézersugaras kezelés paramétereinek optimalizálásával: teljesítmény, az egyes pásztázási ismétlések között eltelt idő, hűtőfolyadék alkalmazása.

\subsection{A lézeres kezelés keltette hullámos felületi szerkezetek jellemzése}

Ha az alkalmazott energiasűrüség a hiperszublimációs küszöb közelében van, de nem éri el azt, akkor a lézersugárral pásztázott vonalak nyomában kialakul az angolul LIPSS-ként emlegetett, hullámos felületszerkezet, amelynek periódusa körülbelül a beeső lézersugárzás hullámhosszának felel meg. A hullámos felület mélysége, morfológiája (így erősítési faktora is) az alkalmazott lézerparaméterektől függ, így dolgozatunkban csak két jellegzetesebb mintát mutatunk be (lásd 3-4. ábra).

A szilícium egykristály strukturált felületére 150 nm vastagságú aranyréteget gőzöltünk, majd Raman-spektrométer segítségével meghatároztuk az erősítési faktorát. Mintaként benzofenonoldatot cseppentettünk a szubsztrátra, majd a strukturálatlan, de arannyal bevont felületen mért ben-

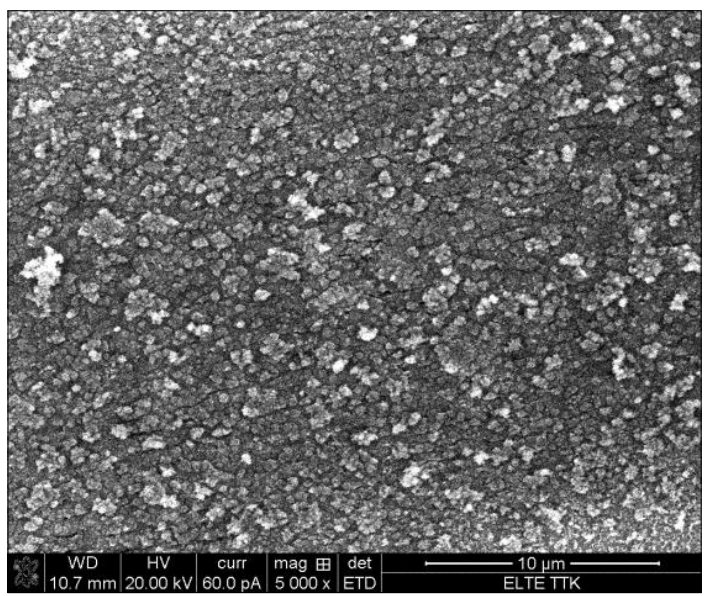

4. ábra. A 490× erösítési faktorú minta SEM-felvétele, aranyozás elött 
zofenonjelet referenciaként véve meghatároztuk a strukturált és aranyozott felületeink erősítési faktorát. Ez egyik esetben 360×, másik esetben 490× adódott. A Raman-vizsgálatnál használt gerjesztőlézer hullámhossza $610 \mathrm{~nm}$ volt, az expozíciós idő pedig 1 másodperc.

A két minta pásztázási sebességében különbözött: a nagyobb erősítési faktorú minta esetén a pásztázási sebesség egy nagyságrenddel kisebb volt, mint a másiknál. Az erősítési faktor növelésének a homogén, több kisméretű szemcséből összeálló struktúra kedvez, amit lassúbb pásztázással lehet elérni.

\section{Következtetések}

A munkánk során különböző felületeket alakítottunk ki szilícium egykristályon, femtoszekundumos lézer segítségével.

Az előmunkált mikrooszlop femtoszekundumos lézeres kimunkálásával jelentősen lecsökkentettük a FIB-bel történő megmunkálási időt, de a hőhatásövezet vastagságának csökkentése érdekében érdemes tovább optimalizálni a lézersugaras paramétereket.

Az általunk kialakított lézerindukált periodikus felületi struktúrák 150 nm-es aranybevonattal nagymértékben erősíti a benzofenon Raman-jelét. Tervezzük tovább növelni az erősítési faktort, valamint más mintamolekulákkal és gerjesztőlézerrel is elvégezni a méréseket.

Tervezzük továbbá a strukturált felületek tribológiai tulajdonságainak vizsgálatát.

\section{Szakirodalmi hivatkozások}

[1] Mangirdas M., Albertas Ž., Satoshi H., Yoshio H., Vygantas M., Ričardas B., Saulius J.: Ultrafast laser processing of materials: from science to industry. Light: Science \& Applications, 5. (2016) 16-133.

[2] Mathis A., Courvoisiera F., Froehly L., Furfaro L., Jacquot M., Lacourt P. A., Dudley J. M.: Micromachining along a curve. Femtosecond laser micromachining of curved profiles in diamond and silicon using accelerating beams. Applied Physics Letters, 101. (2012) 71-110.

https://doi.org/10.1063/1.4745925

[3] Evgeny L.: Mechanisms of femtosecond LIPSS formation induced by periodic surface temperature modulation. Applied Surface Science, 374. (2016) 30.

[4] Kaiwen D., Cong W., Yu Z., Zheng X., Zhi L., Shu M., Biwei W.: One-step fabrication of multifunctional fusiform hierarchical micro/nanostructures on copper by femtosecond laser. Surface and Coatings Technology, 367. (2019) 244-251.

https://doi.org/10.1016/j.surfcoat.2019.04.005
[5] Rafael R. G., Eric M.: Femtosecond laser micromachining in transparent materials. Nature Photonics, 2. (2008) 219-225.

[6] Andrius M., Saulius J., Mitsuru W., Masafumi M., Shigeki M., Hiroaki M., Junji N.: Femtosecond laser-assisted three-dimensional microfabrication in silica. Optics Letters, 26/5. (2001) 277-279. https://doi.org/10.1364/OL.26.000277

[7] Akarapu S., Zbib H. M., Bahr D. F.: Analysis of heterogeneous deformation and dislocation dynamics in single crystal micropillars under compression. International Journal of Plasticity, 26/2. (2010) 239-257.

https://doi.org/10.1016/j.ijplas.2009.06.005

[8] Aifantis E. C.: Gradient Deformation Models at Nano, Micro, and Macro Scales. Journal of Engineering Materials and Technology, 121/2. (1999) 189-202.

[9] Eduardo B.: Interpretation of the size effects in micropillar compression by a strain gradient crystal plasticity theory. International Journal of Plasticity, 116. (2019) 31.

https://doi.org/10.1016/j.ijplas.2019.01.011

[10] Tanga H., Schwarzb K. W., Espinosaa H. D.: Dislocation escape-related size effects in single-crystal micropillars under uniaxial compression. Acta Materialia, 55/5. (2007) 1607-1616. https://doi.org/10.1016/j.actamat.2006.10.021

[11] William D., Nix Seok W. L.: Micro-pillar plasticity controlled by dislocation nucleation at surfaces. Philosophical Magazine, 91/7-9. (2011) 10841096.

https://doi.org/10.1080/14786435.2010.502141

[12] Jijo E. G., Unnikrishnan V. K., Deepak M., Santhosh C., Sajan D. G.: Flexible Superhydrophobic SERS Substrates Fabricated by In Situ Reduction of Ag on Femtosecond Laser-Written Hierarchical Surfaces. Sensors and Actuators B, 272/1. (2018) 485-493.

https://doi.org/10.1016/j.snb.2018.05.155

[13] Steven E. J. B., Narayana M. S. S.: Surface-Enhanced Raman Spectroscopy (SERS) for Sub-Micromolar Detection of DNA/RNA Mononucleotides. Journal of the American Chemical Society, 128/49. (2006) 15580-15581. https://doi.org/10.1021/ja066263w

[14] Ximei Q., Jun L., Shuming N.: Stimuli-Responsive SERS Nanoparticles. Conformational Control of Plasmonic Coupling and Surface Raman Enhancement. Journal of the American Chemical Society, 131/22. (2009) 7540-7541.

https://doi.org/10.1021/ja902226z

[15] Zhu Z., Yan Z., Zhan P., Wang Z.: Large-area surface-enhanced Raman scattering-active substrates fabricated by femtosecond laser ablation. Science China Physics, Mechanics and Astronomy, 56. (2013) 1806-1809. 